\title{
Serological approaches of Typhoid fever
}

S. Sarasombath, S. Korbsrisate, N. Banchuin, A. Thanomsakyuth, T. Sukosol, P. Ekpo

\begin{abstract}
Abstrak
Berbagai pendekatan untuk diagnosis serologik demam tifoid telah mengungkapkan bahwa S. typhi mempunyai sedikit epitop spesifik yang berlokasi dalam berbagai komponen sel yang berbeda seperti protein flagel (flagellin), protein membran luar, O-polisakarida LPS, polisakarida Vi kapsul. Banyak upaya telah dilakukan dengan berbagai metoda untuk mendeteksi antigen spesifik dan antibodi anti S. typhi dalam serum dan antigen dalam urine pasien tifoid. Dibandingkan dengan tes konvensional Widal, upaya tersebut memperlihatkan kelebihan dalam spesivisitas dan sensitivitas. Hasil kerja kami yang terbaru dengan flagellin S. typhi mengungkapkan bahwa epitop spesifik S. typhi yang berlokasi dalam 126 asam amino pada bagian tengah flagellin memberikan hasil yang menjanjikan ketika digunakan dalam ELISA untuk mendeteksi IgM spesifik dalam serum pasien tifoid akut. Penelitian ini meliputi kasus demam tifoid yang terbukti dengan kultur darah (92), salmonellosis non tifoid (31), bakteriemi gram negatif lain dan gram positif (34), 13 kasus demam berdarah dengue dan 116 kasus anak dan dewasa sehat. Lama tes adalah 8 jam dan tes tersebut memberikan spesivisitas 98,97\%, sensitivitas $83,70 \%$, efektivitas $94,05 \%$ dengan nilai duga positif dan negatif masing-masing 97,45\% dan 92,75\%.
\end{abstract}

\begin{abstract}
Several approaches for serological diagnosis of typhoid fever have revealed that $S$. typhi has few specific epitopes which locate in different components of its cell, i.e. flagella protein (flagellin), outer membrane protein, O-polysaccharide of LPS, capsular Vi polysaccharide. Many attempts have been made by various means to detect both specific antigen and antibody of $S$. typhi in sera and antigen in urine of typhoid patients. In comparison with conventional Widal test, these attempts show more advantages in both specificity and sensitivity. Our recent work with flagellin of S. typhi reveals that the specific epitope of S. typhi which located within 126 amino acid in the mid portion of flagellin gives the promising result when used in ELISA detecting specific IgM in acute sera of typhoid patients. The study included hemoculture proven cases of typhoid fever (92), nontyphoid salmonellosis (31), other gram negative and positive bacteremia (34), 13 cases of dengue hemorrhagic fever and 116 cases of healthy children and adults. The assay time is 8 hours. It provides $98.97 \%$ specificity, $83.70 \%$ sensitivity, $94.05 \%$ efficacy with positive and negative predictive value of $97.45 \%$ and $92.75 \%$ respectively.
\end{abstract}

The best method for diagnosis of typhoid fever is isolation of $S$. typhi from bone marrow, blood, stool/rectal swab, and urine. Bone marrow culture has been proven to be the most sensitive diagnostic test but may not be feasible in all clinically suspected cases. ${ }^{1}$ Blood, stool/rectal swab and urine culture have been found to detect $S$. typhi in moderate number of patients with typhoid fever 2 . However, their usefulness is limited by many factors, for instances : stage of the disease, type of culture medium used, the length of the incubation period and previous antibiotic therapy. Thus, the chance to have false negative results are rather high.

Recently, a PCR based test was developed for the detection of $S$. typhi genome in the blood of typhoid patients $^{3}$. It is a favorably specific test when the unique DNA sequences of $S$. typhi are used as primers.

Department of Immunology, Faculty of Medicine Siriraj Hospital, Mahidol University, Bangkok 10700, Thailand
However, this test has some disadvantages for the rural areas in developing countries, such as high cost per test, expensive instruments and required well trained personnel to handle the test. These disadvantages make PCR based test is not adopted for the routine laboratory service in developing countries yet.

The most commonly used diagnostic modality for typhoid fever is serological test which detected either $S$. typhi antigen or antibody to $S$. typhi in clinical specimens of typhoid patients. The test requires highly specific antibody or antigen to detect the corresponding antigen or antibody during proper stage of the disease. The conventional Widal test which is widely used for detect antibody employed whole bacterial cells agglutinate with patient's serum. It is a cheap assay, easy to perform, no need for expensive instrument and well trained personnel. A fourfold rising of antibody titer in paired sera is considered significant, but paired sera are seldom available. A single Widal test is not satisfactory in both specificity and sensitivity and is of dubious significance in the endemic area because of its cross-reactivity with nontyphoidal salmonellae and other enterobacteriaceae 4. 
Thus, the disadvantage of Widal test in both specificity and sensitivity make many researchers seek for the new serological tests that provide better specificity and sensitivity.

Over the last decade, many attempts have been made to produce best specific antigen and antibody for use in serological assays with the hope that these assays would replace Widal test. The data from several reports have revealed that $S$. typhi has more than one specific epitope. These epitopes locate in different components of bacterial cell, i.e. flagellar protein (flagellin), outer membrane protein (OMP), O-polysaccharide of LPS, capsular Vi polysaccharide. The monoclonal antibodies (MAbs) against these epitopes have been established by many investigators. The unique epitopes of $S$. typhi have been identified and produced by either immunochemical or biotechnological means. The serological assays using those MAbs or unique epitopes of $S$. typhi have been set up. All assays have shown promising results such that they were better than Widal test in both specificity and sensitivity.

\section{Flagella protein (Flagellin)}

The flagellar filaments of Salmonella have 2 structurally and antigenically distinct phase- 1 and phase- 2 flagellins which express at different time in one bacterial cell. $S$. typhi express only phase-1 flagellin at all times.

The phase-1 flagellin of S. typhi contains specific "d" antigen. This "d" antigen can be found in phase-1 flagellin of several salmonella serogroups, for example : serogroup B (i.e., S. tanley, S. eppendorf), serogroup C (i.e., S. munchen, $S$. isangi, S. livingstone), serogroup D (i.e., $S$. typhi, $S$. strasbourg), serogroup E (i.e., S. birmingham), etc. Among those salmonellae which have phase-1 d flagellin antigen, only $S$. typhi can cause typhoid fever in human.

The approaches to detect $S$. typhi phase- 1 d flagellin antigen in sera of typhoid patients by monoclonal antibodies were reported in 1990 by Sadallah et al6 and Ekpo et $a l$. Both groups established monoclonal antibodies which were highly specific to $S$. typhi. These MAbs reacted with $52 \mathrm{KD}$ salmonella phase-1 d flagellin6-8. With their MAbs, Sadallah and her colleagues developed a double antibody sandwich ELISA which was successfully used for laboratory diagnosis of typhoid fever. This assay could detect $S$. typhi flagellin in $95.5 \%$ of patients who had hemoculture positive for $S$. typhi6. Double antibody sandwich ELISA using MAbs developed by Ekpo $e t$ al could detect $10 \mathrm{ng} / \mathrm{ml}$ of their specific antigen in the experimental model but failed to detect such antigen in patients' sera?

Flagellin is protein which is a T-dependent antigen. The first antibody response to this type of antigen is IgM class which will switch to IgG class later during the course of disease and convalescent stage. In typhoid fever, detection of IgM specific to unique epitope of $S$. typhi flagellin in acute sera of patients should be beneficial for diagnosis of this disease.

The approach to identify unique epitope of $S$. typhi phase-1 d flagellin was attempted. Sukosol et al successfully obtained the nucleotide sequences 'of the whole $S$. typhi phase- $1 \mathrm{~d}$ flagellin gene and noticed that the middle portion of this genome had lower degree of homology with the nucleotide sequences of phase- 1 flagellin of other salmonellae ${ }^{9}$. Both ends of the gene were genetically deleted and the remaining middle portion containing nucleotides position 4361339 was cloned into an expression vector pGEX$3 \mathrm{X}$, then transformed into E. coli JM 10110 . The protein product of recombinant gene was 302 amino acid in length, locating on the flagellin region IV-VI according to Wei and Joys classification ${ }^{11}$. This protein was specific to MAbs established by Ekpo, et al7. Although this protein antigen could detect IgM in acute sera of typhoid patients, it also reacted with sera of few patients who were infected with salmonella nonphase- $1 \mathrm{~d}$ flagellin as well as other gram negative bacteria. This finding indicated that the 302 amino acid antigen still contained common epitopes with other salmonellae and enterobacteriaceae.

Further approach to obtain a more specific antigen of $S$. typhi based on the phase-1 d flagellin was performed by Korbsrisate et al ${ }^{8}$. The hypervariable region IV, IV-VI and V-VI of S. typhi phase-1 d flagellin gene were amplified by PCR technique, and cloned into expression vector pGEX-2T, then transformed into E. coli TG1. MAbs specific to phase-1 d flagellin of $S$. typhi could react with protein products from hypervariable gene region IV and IV-VI but not with that from region V-VI. This finding indicated that the specific epitope of $S$. typhi was located in hypervariable region IV of phase- $1 \mathrm{~d}$ flagellin.

The protein product from the hypervariable region IV is 126 amino acid in length and has the molecular weight of $13 \mathrm{KD}$ (encoded by nucleotides position 
532-909). Using this antigen, they have developed an indirect ELISA to detect IgM in acute sera of typhoid patients. The samples included 92 hemoculture proven cases of typhoid fever, 31 cases of non-typhoid salmonellosis, 34 cases of gram negative and gram positive bacteremia, 13 cases of dengue hemorrhagic fever, and 116 cases of healthy children and adults. The assay time is 8 hours. The result is shown in Table 1. It provides $98.97 \%$ specificity, $83.70 \%$ sensitivity, $94.05 \%$ efficacy, 97.45 and $92.75 \%$ positive and negative predictive values, respectively. They have concluded that although this unique epitope of $S$. typhi can be found in other salmonellae which have the same phase- $1 \mathrm{~d}$ flagellin, this will be relatively little importance since human infected with those salmonellae except $S$. typhi is very rare and only $S$. typhi can cause clinical manifestation of typhoid fever. Thus, it will not be a problem for use this antigen in serodiagnosis of this disease.

Table 1 The findings of indirect ELISA for detection of IgM antibody to specific epitope on $S$. typhi phase-1 d flagellin.

\begin{tabular}{lrcc}
\hline \multirow{2}{*}{ Group } & Total & \multicolumn{2}{c}{ ELISA } \\
\cline { 3 - 4 } & & $\begin{array}{c}\text { positive } \\
(\%)\end{array}$ & $\begin{array}{c}\text { negative } \\
(\%)\end{array}$ \\
\hline S. typhi & 92 & $77(83.7)$ & $15(16.3)$ \\
Non-typhoid Salmonella & 31 & $0(0)$ & $31(100)$ \\
Other bacteria: gram negative & 19 & $0(0)$ & $19(100)$ \\
$\quad$ gram positive & 15 & $0(0)$ & $15(100)$ \\
Dengue hemorthagic fever & 13 & $0(0)$ & $13(100)$ \\
Normal subjects & 116 & $2(1.7)$ & $114(98.3)$ \\
\hline Total & 286 & 79 & 207 \\
\hline
\end{tabular}

\section{Outer membrane protein}

The outer membrane is the outermost layer of cell envelope of gram-negative bacteria. It consists of lipopolysaccharide (LPS), lipoproteins and the outer membrane protein (OMP) 12 .

In $S$. typhi, three major OMPs have been found and designated OmpC, OmpF and OmpA ${ }^{13}$. The antibody responses to OMP in typhoid patients have shown various degree of specificity in different OMP preparations, depended mainly on purity of the preparation. The detections of antibody to $S$. typhi OMPs have been used for serodiagnosis of typhoid fever.
Calderon et al were the first group to report the significance of specific IgG response to OMP in sera of Chilean typhoid patients ${ }^{14}$.

Ortiz et al used immunoblot for detection of class specific antibody response to OMPs in Mexican typhoid patients 15 .

Ismail et al reported the specific antibody response of typhoid patients to $50 \mathrm{KD}$ OMP. ${ }^{16}$ Her group has developed a dot enzyme immunoassay using $50 \mathrm{KD}$ OMP as antigen detected IgM and IgG antibodies in sera of Malaysian typhoid patients. The sensitivity and specificity of the assay were $90 \%$ and $91 \%$ respectively where either $\operatorname{IgM}$ or $\operatorname{IgG}$ was positive. The specificity of the assay increased to $100 \%$ when IgM was positive alone. For IgG positive alone, the specificity was much reduced 17 .

Verdugo-Rodriguez et al developed enzyme immunoassay using $S$. typhi OMP as antigen to detect antiOMP antibodies in acute sera of typhoid patients. The assay gave a favorably result. They concluded that the EIA using OMP without LPS contamination might be useful for the diagnosis of typhoid fever ${ }^{18}$.

Nandakumar et al used porins of S. typhi detected anti-porins antibodies in typhoid patients by inhibition ELISA. The assay was promising for use as serodiagnosis of typhoid fever. The sensitivity, specificity, accuracy, positive and negative predictive value of this assay were $94.1 \%, 98.7 \%, 97.8 \%, 94.1 \%$ and $98.7 \%$ respectively 19 .

In reviewing those studies, there is still a question about the nature of specific epitopes in OMP of S. typhi. Further identification and purification of these epitopes would be beneficial for the study of immune responses as well as diagnostic modality in this disease.

\section{O-polysaccharide of LPS}

Lipopolysaccharide (LPS) is a unique constituent of the gram negative bacteria. It locates in the outermost layer of bacterial outer membrane. LPS is composed of three parts: the proximal hydrophobic lipid A region, the middle core polysaccharide region and the distal hydrophilic $\mathrm{O}$ antigen polysaccharide region 12 . The core polysaccharide antigens are common in all salmonellae, the antigen specificity of each salmonella serogroup is located in the distal $O$ antigen polysaccharide region. For salmonella serogroup D, the polysaccharide antigen 9 in the distal region of LPS has been reported to be specific for $S$. typhi as 
well as other salmonella in this serogroup 20,21 .

The monoclonal antibody specific for serogroup D salmonella antigen 9 was established by Chaicumpa, et al. ${ }^{20}$ They used this MAb in an indirect ELISA and a dot blot immunoassay to detect the "antigen 9" in urine of typhoid patients. The assays provided 100\% specificity and could detect as little as $7.8 \mathrm{ng}$ of antigen in the urine. The sensitivity of the assay was increased from $65 \%$ when performed on a single specimen to $95 \%$ when serially collected urine samples from a patient were tested. They recommended both assays to be tested for antigen 9 in serially collected urine from typhoid patients, since $S$. typhi antigen is intermittently excreted in the urine of patients 21 .

The attempt to use anti-LPS of $S$. typhi for diagnosis of typhoid fever is reported by Shaheen, et al 22 .They determined the serum levels of $\operatorname{IgM}, \operatorname{IgA}, \operatorname{IgG}$ and IgG subclass to $S$. typhi LPS in 40 typhoid patients and 66 patients for whom diseases other than typhoid were diagnosed. Using multivariate regression modeling, they suggested that detecting IgA, IgG and $\operatorname{IgG} 2$ to $S$. typhi LPS is of diagnostic value for typhoid fever.

\section{Capsular Vi polysaccharide}

The Vi polysaccharide is located on the outermost layer of bacterial outer membrane. This antigen is presented in limited strains of bacteria, i.e., S. typhi, $S$. paratyphi C, C. freundii and some strain of $S$. $d u b$ lins ${ }^{23}$. Among these 4 bacteria, only $S$. typhi and $S$. paratyphi $\mathrm{C}$ can cause clinical manifestations of typhoid fever. S. paratyphi C infection is very rare and responds to the same antibiotic treatment as $S$. typhi. Thus, Vi polysaccharide antigen is of interest to be used as another unique antigen of $S$. typhi for diagnosis of typhoid fever.

For detection of Vi polysaccharide antigen in blood and urine of typhoid patients, Rockhill, et al24 used slide coagglutination with commercial rabbit polyclonal anti-Vi antibody detected $\mathrm{Vi}$ antigen in urine of 96 clinically suspected cases of typhoid fever and 46 healthy control subjects. The assay detected Vi antigen in $97 \%$ of bacteriologically confirmed typhoid fever and $17 \%$ of healthy control. They claimed that this assay can be used for screening patients with suspected typhoid fever even the specificity and sensitivity are not very sastisfied.

In contrary, Taylor, et al 25 developed ELISA and slide coagglutination with rabbit polyclonal anti-Citrobac- ter $\mathrm{Vi}$ antibody to detect $\mathrm{Vi}$ antigen in urine of patients. The results showed low specificity and sensitivity of the assays which suggested that the polyclonal $\mathrm{Vi}$ antibody reagents used in the assays might contain antibodies which cross-react with other bacteria. They concluded that the assays using polyclonal antibodies are of little value for the diagnosis of typhoid fever. The lack of specificity in these assays suggests that more specific antibodies directed to $S$. typhi Vi epitopes should be established.

The monoclonal antibodies to Vi polysaccharide antigen of $S$. typhi have been produced by Pongsunk, et $a{ }^{26}$. All these Mabs are highly specific to Vi antigen of $S$. typhi as well as $\mathrm{Vi}$ antigen of $S$. paratyphi $\mathrm{C}, S$. dublin and $C$. freundii. The slide agglutination test using these Mabs for identification of $S$. typhi colony in primary bacterial culture has worked successfully but failed to detect Vi antigen in urine samples of typhoid patients. They concluded that the established Mabs can replace polyclonal anti-Vi antibodies that have been used routinely for identification of $S$. typhi in primary bacterial culture. For detection of $\mathrm{Vi}$ antigen in clinical specimens, more sensitive assay such as ELISA should be employed.

$\mathrm{Vi}$ polysaccharide is a T-independent antigen. The antibody responses to pure polysaccharide is IgM class only which will not stay last long after the disappearance of this antigen. Therefore, IgM anti-Vi antibody should disappear from the sera of previously $S$. typhi infected individuals and even in the late convalescent stage of the disease. The usefulness of detecting specific IgM to this type of antigen in acute sera of typhoid patients is recognized. We propose that the combined detection of IgM anti-phase-1 d flagellin and $\operatorname{IgM}$ anti- $\mathrm{Vi}$ antigen in acute sera of typhoid patients should be the most benefit for accurate diagnosis of this disease, since no salmonella which have phase-1 d flagellin has Vi polysaccharide, except $S$. typhi.

\section{References}

1. Hoffman SL, Edman DC, Punjabi NH, Lesmana M, Cholid A, Sundah S, et al . Bone marrow aspirate culture superior to

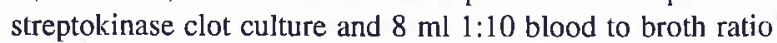
blood culture for diagnosis of typhoid fever. Am J Trop Med Hyg 1986; 35: 836-9.

2. Gilman RH, Terminal M, Levine MM, Hemandez-Mendoza RB. Relative efficacy of blood, urine, rectal swab and rose spot culture. Lancet 1975; 1211-3.

3. Song JH, Cho H, Park MY, Na DS, Moon HB, Pai CH. Detection of Salmonella typhi in the blood of patients with typhoid fever by polymerase chain reaction. J Clin Microbiol 
$1993 ; 31: 1439-43$.

4. Rasaily R, Dutta P, Saha MR, Mitra U, Bhattacharya SK, Manna B, et al. Value of a single Widal test in the diagnosis of typhoid fever. Indian J Med Res 1993; 97: 104-7.

5. Macnab RM. Genetics and biogenesis of bacterial flagella. Ann Rev Genet 1992; 26: 131-58.

6. Sadallah F, Brighouse G, Giudice GD, Drager-Dayal R, Hocine M, Lambert PH. Production of specific monoclonal antibodies to Salmonella typhi flagellin and possible application to immunodiagnosis of typhoid fever. J Infect Dis 1990; 161: 59-64.

7. Ekpo P, Sarasombath S, Banchuin N, Sirisinha S. Monoclonal antibodies to 52-KD protein of Salmonella typhi. J. Clin Microbiol 1990; 28: 1818-21.

8. Korbsrisate S, Thanomsakyuth A, Banchuin N, Hossain M, McKay S, Sarasombath S. Identification of specific epitope of phase 1-d Salmonella flagellin for the diagnosis of typhoid fever 1997. (Manuscript submitted)

9. Sukosol T, Sarasombath S, Mongkolsuk S, Songsivilai S, Chaiyaroj S, Pongsunk S, et al. Molecular cloning and expression of Salmonella typhi flagellin : characterization of 52 KD specific antigen of $S$. typhi. Asian Pac J Allergy Immunol 1993; 11: 57-69.

10. Sukosol T, Sarasombath S, Songsivilai S, Ekpo P, Rungpitarangsi B, Pang T. Fusion protein of Salmonella typhi flagellin as antigen for diagnosis of typhoid fever. Asian Pac J Allergy Immunol 1994; 12: 21-5.

11. Wei LN, Joys TM. Covalent structure of three phase-1 flagellin filament proteins of Salmonella. Mol Biol 1985; 186: 791-803.

12. Nikaido $H$, Vaara $M$. Molecular basis of bacterial outer membrane permeability. Microbiol Rev 1985; 49: 1-32.

13. Puente JL, Verdugo-Rodriguez A, Calva E. Expressive of $S$. typhi and $E$. coli OmpC is influenced differently by medium osmolarity; dependence on E. coli OmpR. Mol Microbiol 1991; 5: 1205-10.

14. Calderón I, Lobos SR, Rojas HA, Palomino C, Rodriguez, LH, Mora GC. Antibodies to porin antigens of $S$. typhi induced during typhoid fever in humans. Infect Immun 1986; 52: 209-12.

15. Ortiz V, Isibasi A, Garcia-Ortigoza E, Kumate J, Immunoblot detection of class-specific humoral immune response to outer membrane proteins isolated from $S$. typhi in humans with typhoid fever. J Clin Microb 1989; 27: 1640-5.
16. Ismail A, Hai OK, Kader ZA. Demonstration of an antigenic protein specific for $S$. typhi. Biochem Biophys Res Comm 1991; 181: 301-5.

17. Jackson AA, Ismail A, Ibrahim TA, Kader ZS, Nawi NM Retrospective review of dot enzyme immunoassay test for typhoid fever in an endernic area. Southeast Asian J Trop Med Public Health 1995; 26: 625-30.

18. Verdugo-Rodriguez A, Lopez-Vidal Y, Puente JL, RuizPlacios GM, Calva E. Early diagnosis of typhoid fever by an enzyme immunoassay using Salmonella typhi onter membrane protein preparations. Eur J Clin Microbiol and Infect Dis 1993 ; 12: 248-54.

19. Nandakumar KS, Palanivel V, Muthukkaruppan V.Diagnosis of typhoid fever : detection of Salmonella typhi porins-specific antibodies by inhibition ELISA. Clin Exp Immunol 1993; 94: 317-21.

20. Chaicumpa W, Thin-inta W, Khusmith S, Tapchaisri P, Echeverria $\mathrm{P}$, Kalambaheti $\mathrm{T}$, et al. Detection with monoclonal antibody of Salmonella typhi antigen 9 in specimens from patients. J Clin Microbiol 1988; 26: 1824-30.

21. Chaicumpa W, Ruangkunaporn Y, Burr D, Chongsa-nguan M, Echeverria, P. Diagnosis of typhoid fever by detection of Salmonella typhi antigen in urine. J Clin Microbiol 1992; 30: 2513-15.

22. Shaheen HI, Girgis NI, Rodier GR, Kamal KA. Evaluation of the response of human humoral antibodies to Salmonella typhi lipopolysaccharide in an area of endemic typhoid fever. Clin Infect Dis 1995; 21: 1012-3.

23. Edwards PR, Ewing WH. Edentification of Enterobacteriaceae, $3^{\text {rd }}$ ed. Burgess Publishing Company, Minnesota $1972 ; 208-58$.

24. Rockhill RC, Rumans LW, Lesmana M, Dennis DT. Detection of Salmonella typhi D, Vi and d antigens, by slide coagglutination, in urine from patients with typhoid fever. J Clin Microbiol 1980; 11: 213-6.

25. Taylor DN, Harris JR, Barrett TJ, Hargrett NT, Prentzel I, Valdivieso $\mathrm{C}$, et al. Detection of urinary $\mathrm{Vi}$ antigen as a diagnostic test for typhoid fever. J Clin Microbiol 1983; 18: $872-6$.

26. Pongsunk S, Sarasombath S, Ekpo P, Tangtherawattana P, Levine MM. Production of monoclonal antibodies to Vi polysaccharide antigen of Salmonella typhi. Asian Pac J Allergy Immunol 1993; 11: 53-6. 